\title{
Assessment of salinity-induced photorespiratory glycolate metabolism in Anabaena sp. PCC 7120
}

\section{Correspondence \\ Brett A. Neilan \\ b.neilan@unsw.edu.au}

Received 23 September 2010

Revised 28 November 2010

Accepted 13 December 2010

\author{
Ashish Kumar Srivastava, ${ }^{1,2}$ Ralitza Alexova, ${ }^{2}$ Young Jae Jeon, ${ }^{2}$ \\ Gurjeet S. Kohli ${ }^{2}$ and Brett A. Neilan ${ }^{2}$
}

\author{
${ }^{1}$ Department of Botany, School of Life Sciences, Mizoram University, Tanhril Campus, \\ Aizawl 796004, India \\ ${ }^{2}$ School of Biotechnology and Biomolecular Sciences, The University of New South Wales, Sydney, \\ NSW 2052, Australia
}

This paper reports an investigation of salinity-induced glycolate metabolism in the cyanobacterium Anabaena sp. PCC 7120 (hereafter Anabaena PCC 7120). Quantitative analysis of transcripts for the photosynthesis-associated genes encoding ribulose-1,5-bisphosphate carboxylase oxygenase (Rubisco), phosphoribulokinase and transketolase, as well as those involved in glycolate metabolism (phosphoglycolate phosphatase, glycolate oxidase, alanine-glyoxylate aminotransferase and serine hydroxymethyltransferase) was performed. The expression of all investigated photosynthesis-associated genes except Rubisco was downregulated after $24 \mathrm{~h}$ $\mathrm{NaCl}$ treatment. However, under the same conditions, the transcripts encoding enzymes involved in glycolate metabolism were overexpressed. This was further confirmed by the quantitative analysis of the intermediates involved in glycolate metabolism. The intracellular levels of organic acids (glyceric, glycolic and glyoxylic acids) and amino acids (glycine and serine) were elevated in salt-treated cells as compared to those in the control cells. Transcriptional inhibition of photosynthesis-associated genes, and upregulation of genes and enhanced synthesis of intermediates associated with glycolate metabolism, indicate the occurrence of this photorespiratory metabolic pathway metabolism in Anabaena PCC 7120 under salt stress.

\section{INTRODUCTION}

The evolution of cyanobacteria over 2.7 billion years significantly contributed to a major transition in the history of life on Earth (Buick, 1992). Cyanobacterial photosynthesis resulted in a tremendous increase in the oxygen concentration of the atmosphere and the emergence of oxygen-dependent life. Due to their ability to adapt frequently to changing environments, cyanobacteria currently occupy most ecological niches on our planet.

An important habitat for cyanobacteria is rice fields, where they significantly contribute to the availability of nitrogen for the crop (Singh, 1961). The rice agro-ecosystem, including cyanobacteria, is subjected to several abiotic stresses, including salt stress caused by anthropogenic activities (Srivastava et al., 2009). It has been reported that high salinity not only inhibits photosynthesis and hence the carbon pool of freshwater cyanobacteria (Srivastava et al., 2008) but also decreases the amount of fixed carbon available for the synthesis of compatible solutes (Ferjani

Abbreviations: DEPC, diethylpyrocarbonate; Rubisco, ribulose-1,5bisphosphate carboxylase oxygenase.

The GenBank/EMBL/DDBJ accession numbers for the sequences determined in this study are GU560731-GU560737. et al., 2003). Responses of freshwater cyanobacteria to salt stress have been studied by several research groups at the genomic, transcriptomic and proteomic levels (Fulda et al., 2006; Huang et al., 2006; Kanesaki et al., 2002; Marin et al., 2004; Srivastava et al., 2008). These studies reported salt stress responses of several cyanobacterial species in relation to specific genes encoding stress proteins, photosynthetic proteins and proteins involved in the synthesis of compatible solutes. However, salinity-induced changes in metabolism related to glycolate metabolism (photorespiration) have been little studied in cyanobacteria.

Photorespiration evolved as an essential disadvantage of oxygenic life, as this pathway utilizes about a quarter of the carbon fixed from photosynthesis (Eckardt, 2005). It widely depends on the activity of type I ribulose-1,5bisphosphate carboxylase oxygenase (Rubisco), commonly found in cyanobacteria, algae and higher plants, which has both carboxylase and oxygenase activity. However, cyanobacterial type I Rubisco has a low affinity for carbon dioxide and therefore cyanobacteria have evolved a carbonconcentrating mechanism. By placing this enzyme in carboxysomes, an increase in $\mathrm{CO}_{2}$ concentration (about 1000 -fold) around the active site of the protein occurs (Badger \& Price, 2003). 
The existence of photorespiration in cyanobacteria has been questioned (Colman \& Norman, 1997). Several reports have dealt with discrete biochemical reactions related to photorespiration (Bergman et al., 1984; Eisenhut et al., 2006, 2008; Norman \& Colman; 1988; Renström \& Bergman, 1989); most of these studies suggested the presence of an incomplete cyanobacterial photorespiratory glycolate metabolism. However, Bauwe et al. (2010) and Eisenhut et al. (2006) reported that Synechocystis PCC 6803 exhibits glycolate metabolism as well as possessing a glycerate pathway. More recently, Srivastava et al. (2008) proposed glycolate metabolism in Anabaena doliolum exposed to salt stress. However, the physiological and proteomic characterization of salinity-induced glycolate metabolism in A. doliolum using two-dimensional protein gel electrophoresis was interpreted against several methodological variables, including sample preparation, isolelectric focusing strip length, voltage during first dimension and staining procedure (Bhargava et al., 2008; Görg et al., 1999; López, 2007). Thus the present study was designed to validate and build on earlier reports of glycolate metabolism by using transcription analysis of the various enzymes proposed to be involved. Evidence was sought for changes in the expression of these different enzymes and the accumulation of intermediates of the glycolate pathway. Anabaena PCC 7120 was selected as the test organism due to the availability of its published and characterized genome.

To achieve the above-mentioned objectives, quantitative reverse transcription PCR (qRT-PCR) was performed for four genes involved in photorespiration, namely those encoding phosphoglycolate phosphatase (alr4944), glycolate oxidase (all0170), alanine-glyoxylate aminotransferase (alr1004) and serine hydroxymethyltransferase (alr4806), as well as three genes that play a role in carbon fixation: those encoding the Rubisco small subunit (alr1526), phosphoribulokinase (alr2350) and transketolase (alr3344). In addition, intracellular concentrations of metabolic intermediates (glycine, serine, glyceric, glycolic and glyoxylic acids) were determined.

\section{METHODS}

Organism and growth condition. Cultures of Anabaena PCC 7120 were maintained in Jaworski's medium (Thompson et al., 1988) buffered with Tris/ $\mathrm{HCl}(\mathrm{pH} 7.5)$. The culture was grown at $24 \pm 2{ }^{\circ} \mathrm{C}$ under fluorescent tubes emitting $72 \mu \mathrm{mol}$ photons $\mathrm{m}^{-2} \mathrm{~s}^{-1}$ PAR (photosynthetically active radiation) with a photoperiod of $14: 10 \mathrm{~h}$ (light: dark). The cultures were continuously shaken. The experiments were conducted in three sets: (i) cells grown in normal culture conditions, (ii) cells exposed to $150 \mathrm{mM} \mathrm{NaCl}$ for $1 \mathrm{~h}$ and (iii) cells exposed to $150 \mathrm{mM} \mathrm{NaCl}$ for $24 \mathrm{~h}$. This concentration of $\mathrm{NaCl}$ was selected since it is the $\mathrm{LC}_{50}$ dose obtained by the colony count method (Rai \& Raizada, 1985). The selected dose and duration of salt treatment has been found to alter photosynthesis, antioxidative defence and protein profiles in cyanobacteria (Srivastava et al., 2005, 2008). All experiments were performed as independent biological triplicates and repeated twice to confirm the findings.
Gene expression studies of glycolate metabolism and bioinformatic analysis. The gene sequences encoding relevant proteins involved in glycolate metabolism were obtained from the genome of Anabaena PCC 7120 (http://genome.kazusa.or.jp/cyanobase/ Anabaena) and used for primer design. Percentage similarity and identity of those genes to other translated sequences were determined using BLAST in conjunction with the National Center for Biotechnology Information (NCBI, NIH). Primers for photosynthesis-associated genes encoding the Rubisco small subunit, phosphoribulokinase and transketolase, and genes encoding enzymes involved in glycolate metabolism (phosphoglycolate phosphatase, glycolate oxidase, alanine-glyoxylate aminotransferase and serine hydroxymethyltransferase) were designed using Primer-BLAST (http://www. ncbi.nlm.nih.gov/tools/primer-blast/). Details of the primers used in this study are given in Table 1.

DNA isolation, gene amplification and sequencing. Genomic DNA was isolated using the method described by Srivastava et al. (2007). PCR was performed in a $20 \mu \mathrm{l}$ reaction mixture containing 100 ng DNA, PCR buffer, $4.5 \mathrm{mM} \mathrm{MgCl}_{2}, 200 \mu \mathrm{M}$ dNTPs, $10 \mathrm{pmol}$ of each primer and $0.2 \mathrm{U}$ Taq DNA polymerase. Thermal cycling was performed using the following programme: initial denaturation for $5 \mathrm{~min}$ at $94{ }^{\circ} \mathrm{C}$ followed by 35 cycles each consisting of $30 \mathrm{~s}$ denaturation at $94{ }^{\circ} \mathrm{C}, 30 \mathrm{~s}$ annealing at specific temperature depending on primers, $45 \mathrm{~s}$ elongation at $72{ }^{\circ} \mathrm{C}$ and a final $7 \mathrm{~min}$ elongation at $72{ }^{\circ} \mathrm{C}$. PCR products were purified and subjected to automated DNA sequencing using a PRISM BigDye cycle sequencing system with the DNA sequencing reaction containing BigDye, sequencing buffer and $3.2 \mathrm{pmol}$ of either of the primers. Thermal cycling for the sequencing reaction was $96{ }^{\circ} \mathrm{C}$ for $3 \mathrm{~min}, 30$ cycles of $96{ }^{\circ} \mathrm{C}$ for $10 \mathrm{~s}$ and $50{ }^{\circ} \mathrm{C}$ for $5 \mathrm{~s}$, followed by $60{ }^{\circ} \mathrm{C}$ for $4 \mathrm{~min}$. Sequencing was performed to confirm the amplified gene identity. The sequences were submitted to GenBank under accession numbers GU560731 to GU560737.

RNA isolation and DNase treatment. Total RNA was isolated using the method of Schmidt-Goff \& Federspiel (1993). Briefly, $5 \mathrm{ml}$ cyanobacterial culture $\left(\mathrm{OD}_{730} \quad 0.5\right)$ was centrifuged at $5000 \mathrm{~g}$ and frozen in liquid nitrogen for $5 \mathrm{~min}$. This was followed by the addition of $0.5 \mathrm{~mm}$ zirconium silicate beads, $20 \%$ SDS, $3 \%$ celite and Trisbuffered phenol. The aqueous layer was collected after centrifugation and $1 \mathrm{ml}$ chloroform was added. After centrifugation, freshly prepared precipitation buffer (4 M LiCl, $200 \mathrm{mM}$ Tris, $\mathrm{pH}$ 7.5; $10 \mathrm{mM}$ EDTA, $\mathrm{pH} 8.0$ ) was added followed by incubation overnight at $-20{ }^{\circ} \mathrm{C}$. This was followed by centrifugation at $16000 \mathrm{~g}$ and addition of $3 \mathrm{M}$ sodium acetate and $95 \%$ ethanol. After precipitation at $-80{ }^{\circ} \mathrm{C}$, the pellet was collected by centrifugation and resuspended in DEPC-treated water.

DNase treatment was carried out for $4 \mathrm{~h}$ at $37^{\circ} \mathrm{C}$. Twenty nanograms of RNA was treated with $6 \mathrm{U}$ of TURBO DNase (Ambion). This was followed by a TRIzol (Invitrogen) extraction according to the manufacturer's instructions.

Total cDNA synthesis. RNA quantity was estimated using a Nanodrop spectrophotometer (Nanodrop Technologies). To check for DNA contamination in the RNA samples, $16 \mathrm{~S}$ rDNA primers were used in a PCR (Neilan et al., 1997). An equal amount (250 ng) of RNA isolated from control and treated samples was used for cDNA synthesis. Reverse transcription was performed using the First Strand cDNA synthesis kit (Marligen Biosciences) according to the manufacturer's instructions with slight modifications. Synthesis was done in a $20 \mu \mathrm{l}$ reaction as follows: one cycle of $22{ }^{\circ} \mathrm{C}$ for $5 \mathrm{~min}$, two cycles of $42{ }^{\circ} \mathrm{C}$ for $90 \mathrm{~min}$ and one cycle of $85{ }^{\circ} \mathrm{C}$ for $5 \mathrm{~min}$. This was again followed by cDNA quantification using a Nanodrop spectrophotometer.

qRT-PCR. For quantification of transcripts from selected genes of Anabaena PCC 7120 exposed to salt stress, qRT-PCR was performed 
Table 1. Primers used for analysis of selected transcripts of Anabaena PCC 7120

\begin{tabular}{|c|c|c|c|c|c|c|}
\hline Enzyme/product & Gene & Primers & $\begin{array}{l}\text { Annealing } \\
\text { temp. }\left({ }^{\circ} \mathrm{C}\right)\end{array}$ & $\begin{array}{l}\text { Expected } \\
\text { product size } \\
\quad(\text { bp) }\end{array}$ & $\begin{array}{l}\text { Primer } \\
\text { efficiency } \\
(\%)\end{array}$ & Reference \\
\hline Transketolase & alr3344 & F: CGGTTCCCCTAACAAATCTAATACT & 61 & 180 & 100.0 & $\begin{array}{l}\text { Bhargava et al. } \\
\text { (2008) }\end{array}$ \\
\hline & & R: CTTTGTAATCTGCGTAGGTTTTGTT & & & & \\
\hline Phosphoribulokinase & alr 2350 & F: TGACTAATGGTAGTTCTGTGTCAGC & 61 & 175 & 95.0 & $\begin{array}{l}\text { Bhargava et al. } \\
\text { (2008) }\end{array}$ \\
\hline & & R: GTAACTTTGTAGTGTTTCGCCAGTT & & & & \\
\hline Glycolate oxidase & allo170 & $\begin{array}{l}\text { F: ATTAGCCAAATGCAACCCTG } \\
\text { R: CAATGGCGTTTCAATGTTTG }\end{array}$ & 61 & 280 & 99.5 & This study \\
\hline $\begin{array}{l}\text { Phosphoglycolate } \\
\text { phosphatase }\end{array}$ & alr4944 & $\begin{array}{l}\text { F: TGATGGCACGATTGCGGATACC } \\
\text { R: CCGAACTCTACCGCCAAGCG }\end{array}$ & 57 & 70 & 91.0 & This study \\
\hline $\begin{array}{l}\text { Alanine-glyoxylate } \\
\text { aminotransferase }\end{array}$ & alr1004 & $\begin{array}{l}\text { F: CACAGGCGCACGTCAACCCT } \\
\text { R: GGCGAAGCGCCAGGAGAACA }\end{array}$ & 57 & 150 & 97.0 & This study \\
\hline RNA polymerase $(r p o c 1)$ & alr1595 & F: CCTCAGCGAAGATCAATGGT & 57 & 160 & 100.0 & $\begin{array}{l}\text { Ginn et al. } \\
\text { (2010) }\end{array}$ \\
\hline & & R: CCGTTTTTGCCCCTTACTTT & & & & \\
\hline
\end{tabular}

using the RotorGene 3000 thermal cycler (Corbett Research). qRTPCR was performed in a $25 \mu \mathrm{l}$ volume containing $12.5 \mu \mathrm{l}$ enzymenucleotide-dye (SYBR) mix (Invitrogen), $0.5 \mu$ l reference dye (ROX), 10 pmol of each primer and $500 \mathrm{ng}$ cDNA. Negative controls with no cDNA were included. All reactions were done in triplicate. The amplification programme consisted of an initial hold at $60{ }^{\circ} \mathrm{C}$ for $5 \mathrm{~min}$ and denaturation at $95{ }^{\circ} \mathrm{C}$ for $10 \mathrm{~min}$ followed by 40 cycles at $95{ }^{\circ} \mathrm{C}$ for $15 \mathrm{~s}, 61$ or $57{ }^{\circ} \mathrm{C}$ (Table 1 ) for $30 \mathrm{~s}$. The $r p o C 1$ gene was used as a reference for relative quantification of selected transcripts (Ginn et al., 2010). Primer efficiency curves and relative quantification were performed as described by Pfaffl (2001).

Measurement of organic acids. Intracellular glyceric, glycolic and glyoxylic acids were extracted in $80 \%$ ethanol, and the quantities measured by HPLC (Eisenhut et al., 2006) using an Aminex column HPX-87H $(300 \times 7.8)$ (Bio-Rad) equipped with a UV detector. The ethanol extract was dried in a Speedvac concentrator (Savant). MilliQ water was added to the dried samples for analysis of organic acids. The organic acids were detected at $210 \mathrm{~nm}$ using a UV spectrophotometer. Separations were performed at $50{ }^{\circ} \mathrm{C}$ and eluted at $0.6 \mathrm{ml} \mathrm{min}{ }^{-1}$ using $5 \mathrm{mM} \mathrm{H}_{2} \mathrm{SO}_{4}$. The culture medium was also analysed for possible excretion of organic acids. Standards containing analytical-grade components were used to calibrate the system.

Amino acid analysis. Amino acids were extracted in ethanol using the method described by Eisenhut et al. (2006). The ethanol extract was dried in a Speedvac concentrator. MilliQ water was added to the dried samples and sonicated at room temperature. The suspension was centrifuged at $14000 \mathrm{~g}$ and subjected to amino acid analysis using Water AccQTag Ultra chemistry.
Statistical analysis. Results of organic acids and amino acids were statistically analysed using a one-way ANOVA followed by Duncan's new multiple range test (DMRT) using SPSS version 15.0. Three independent variables were considered for each experiment.

\section{RESULTS}

\section{Sequence analysis and primer efficiency}

In order to understand the regulation of the photorespiration pathway under salt-stress conditions in Anabaena PCC 7120, we looked into whole-genome information for this organism and selected candidate genes based on information from previous studies (Eisenhut et al., 2006; Srivastava et al., 2008). The sequences obtained were analysed and compared with the sequences available in GenBank using BLASTN, except for the phosphoglycolate phosphatase gene (alr4944), for which BLASTX was performed. Among those genes, that encoding Rubisco (alr1526) showed $100 \%$ identity to those of $A$. doliolum LCR1. All other genes showed similarity with the respective genes of Anabaena PCC 7120. No significant DNA similarity was observed for the phosphoglycolate phosphatase gene (alr4944) due to the short sequence length; however, translated (BLASTX) analysis revealed $86 \%$ similarity with the same enzyme from Anabaena PCC 7120. Interestingly, none of these genes 
had significant sequence similarity with their counterparts from unicellular cyanobacteria. The efficiency curve for each primer set revealed between 91 and $100 \%$ efficiency (Table 1).

\section{Effect of high salinity on transcription of the selected genes}

Data pertaining to salinity-induced alterations in transcripts of selected genes are shown in Table 2. Among the photosynthesis-related genes in Anabaena PCC 7120 that were investigated, the Rubisco gene (alr1526) from the salt-stressed cells showed 2.6-fold higher expression after $24 \mathrm{~h} \mathrm{NaCl}$ treatment compared to the control cells. However, the other two genes, encoding phosphoribulokinase (alr2350) and transketolase (alr3344), showed approximately 10 - and 3.3-fold lower expression respectively after $24 \mathrm{~h} \mathrm{NaCl}$ treatment compared to the control cells. After $1 \mathrm{~h} \mathrm{NaCl}$ treatment, very similar mRNA expression levels from both salt-treated and control cells were detected.

In contrast to the above results, all genes related to glycolate metabolism, except the gene encoding serine hydroxymethyltransferase (alr4806), showed overexpression after $1 \mathrm{~h}$ salt treatment. The highest induction (7.5fold) was observed for the serine hydroxymethyltransferase gene (alr4806) transcript after $24 \mathrm{~h} \mathrm{NaCl}$ treatment relative to the control. The glycolate oxidase (all0170) and phosphoglycolate phosphatase (alr4944) genes were overexpressed 1.9- and 2.3-fold, respectively, after $24 \mathrm{~h} \mathrm{NaCl}$ treatment. Alanine-glyoxylate aminotransferase (alr1004) was upregulated 1.4- and 6.9-fold after 1 and $24 \mathrm{~h} \mathrm{NaCl}$ treatment, respectively. Transcription of the rpoC1 gene (alr1595), selected as a housekeeping gene, showed insignificant changes in both control and salt-treated cells at both time points.

\section{Organic acid content}

Glyceric, glycolic and glyoxylic acids, which are intermediates involved in glycolate metabolism, were measured to confirm the findings of the transcript analysis described above. Intracellular concentrations of these organic acids increased following $\mathrm{NaCl}$ treatment (Fig. 1a). The glyceric acid content of the cells increased by 2.1- and 3.2-fold after 1 and $24 \mathrm{~h} \mathrm{NaCl}$ treatment, respectively. The glycolic and glyoxylic acid concentrations were 4.2- and 3.9-fold higher, respectively, after $24 \mathrm{~h}$ exposure to $150 \mathrm{mM} \mathrm{NaCl}$ as compared to control.

\section{Amino acid content}

Fig. 1(b) shows the change in concentration of glycine and serine, amino acids which are metabolites of the glycolate pathway. The concentration of both amino acids increased, by 1.9- (glycine) and 2.2-fold (serine), following the $24 \mathrm{~h}$ $\mathrm{NaCl}$ treatment as compared to the control culture. Interestingly, the free alanine concentration was below detection limits in the control cells but after 1 and $24 \mathrm{~h}$ treatment its levels rose to 0.08 and $0.16 \mu \mathrm{g}$ (mg protein $)^{-1}$, respectively.

\section{DISCUSSION}

It is well known that high salinity affects cell growth and inhibits photosynthesis in cyanobacteria (Fulda et al., 1999; Moisander et al., 2002; Srivastava et al., 2005, 2008). Among the genes involved in photosynthesis that were studied here, only alr1526, encoding Rubisco, was overexpressed in response to high concentrations of $\mathrm{NaCl}$. This finding is supported by a previous study by Srivastava $\mathrm{et} \mathrm{al}$. (2008), who reported salinity-induced hyper-accumulation of Rubisco in A. doliolum. Salt stress has been found to induce Rubisco activity and its transcription in Sesbania

Table 2. Change in transcript level of selected genes of Anabaena PCC 7120 exposed to $150 \mathrm{mM}$ $\mathrm{NaCl}$ for 1 and $24 \mathrm{~h}$ as revealed by qRT-PCR analysis

All values are mean \pm SD. Values indicate fold change in the transcripts compared to the non-treated control.

\begin{tabular}{|lcc|}
\hline Gene encoding & \multicolumn{2}{c|}{ Change in transcript level after NaCl exposure for: } \\
\cline { 2 - 3 } & $\mathbf{1 ~ h}$ & $\mathbf{2 4} \mathbf{~ h}$ \\
\hline Rubisco small subunit (alr1526) & $2.40 \pm 0.17^{\star}$ & $2.57 \pm 0.15^{\star}$ \\
Transketolase (alr3344) & $1.14 \pm 0.22$ & $0.33 \pm 0.01 \dagger$ \\
Phosphoribulokinase (alr2350) & $1.20 \pm 0.12$ & $0.12 \pm 0.02 \dagger$ \\
Glycolate oxidase (allo170) & $1.69 \pm 0.15^{\star}$ & $1.93 \pm 0.14^{\star}$ \\
Serine hydroxymethyltransferase (alr4806) & $0.50 \pm 0.11 \dagger$ & $7.51 \pm 0.40^{\star}$ \\
Phosphoglycolate phosphatase (alr4944) & $1.57 \pm 0.13^{\star}$ & $2.30 \pm 0.16^{\star}$ \\
Alanine-glyoxylate aminotransferase (alr1004) & $1.40 \pm 0.13$ & $6.93 \pm 0.19^{\star}$ \\
RNA polymerase (rpoC1, alr1595) & $0.97 \pm 0.11$ & $0.99 \pm 0.09$ \\
\hline
\end{tabular}

' ' and ' $\dagger$ ' indicate significant repression and overexpression, respectively, of transcripts after $150 \mathrm{mM} \mathrm{NaCl}$ treatment compared to control cells. All analyses were performed in triplicate using biologically independent repeats. 

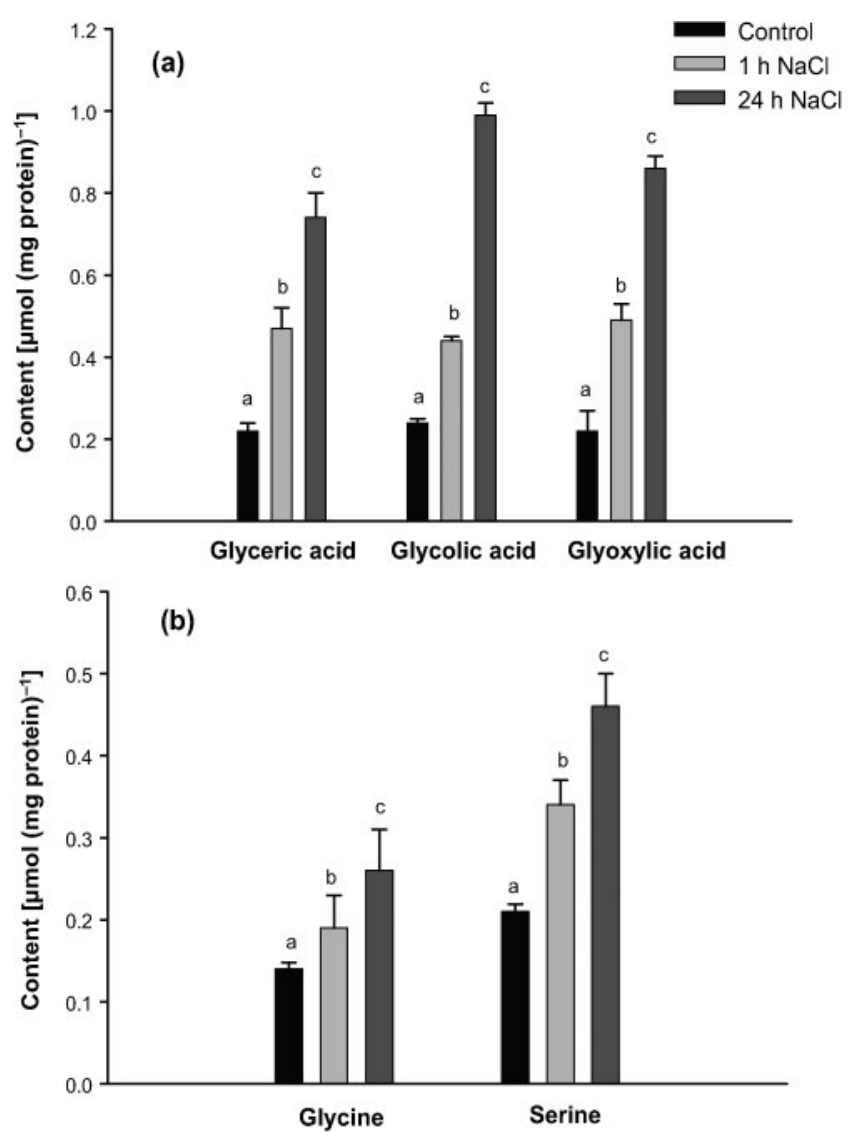

Fig. 1. Contents of (a) organic acids (glyceric, glycolic and glyoxylic acids) and (b) free amino acids (glycine and serine) of control and $150 \mathrm{mM} \mathrm{NaCl}$-treated Anabaena PCC 7120. Error bars show SD. Different analysis was done for each column (Duncan's new multiple range test). Bars with different letters are significantly different $(P<0.01)$.

and alfalfa (Sivakumar et al., 2000; Winicov \& Seemann, 1990). In contrast to the Rubisco gene, transcription of the phosphoribulokinase (alr2350) and transketolase (alr3344) genes was downregulated after $24 \mathrm{~h} \mathrm{NaCl}$ treatment, suggesting inhibition of carbon assimilation under highsalinity conditions. Similar findings were also reported by Seki et al. (2002) and Chaves et al. (2009). A decrease in carbon assimilation may also be attributed to the selective inhibition of photosystem II as reflected in NADPH production (Lu \& Zhang, 2000; Srivastava et al., 2008; Sudhir et al., 2005). An enhanced oxygenase activity of Rubisco is therefore postulated due to a reduction in photosynthetic carbon assimilation that may decrease the amount of carbon in the carboxysome, exposing Rubisco to a higher oxygen partial pressure.

All genes related to the glycolate metabolic pathway showed upregulation after salt treatment for $24 \mathrm{~h}$. Overexpression of the glycolate oxidase gene (all0170) supports the observations of Srivastava et al. (2008), who reported increased enzyme activity in A. doliolum exposed to salt stress. Betsche et al. (1992) also reported glycolate oxidase activity in the endosymbiotic cyanobacterium Cyanophora paradoxa. Likewise, overexpression of phosphoglycolate phosphatase during the salt stress response observed in this study was also shown by Chaves et al. (2009). It is worth mentioning that the genome analysis of Anabaena PCC 7120 suggested that it has no homologue to the glutamate-glyoxylate aminotransferase gene of Synechocystis PCC 6803 (Eisenhut et al., 2006). Instead, Anabaena PCC 7120 has an alanine-glyoxylate aminotransferase (alr1004) gene, which showed upregulation under salt stress conditions (Table 2). Although the cellular alanine content was below the detection limit of the assay in the untreated cells, elevated levels were found in the salttreated cultures. Upregulation of alanine-glyoxylate aminotransferase (alr1004) together with the hyper-accumulation of alanine suggest the possible involvement of this enzyme in the glycolate metabolism of Anabaena PCC 7120. In contrast to this, Renström-Kellner \& Bergman (1989) suggested the glutamate-mediated conversion of glyoxylate to glycine by a glutamate-glyoxylate aminotransferase in Anabaena cylindrica.

Overexpression of serine hydroxymethyltransferase (alr4806) after $24 \mathrm{~h} \mathrm{NaCl}$ treatment is reflected by the increased accumulation of serine in the cell (Fig. 1b). Serine hydroxymethyltransferase activity was not reported in Coccochloris peniocystis (Norman \& Colman, 1992); however, significant activity was reported in Synechocystis PCC 6803 (Eisenhut et al., 2006). The genome of Anabaena PCC 7120 also suggests probable absence of genes involved in a bacterial-like glycerate pathway, as in $S y$ nechocystis PCC 6803 (Eisenhut et al., 2006). The relatively lower upregulation of these genes may be due to the specific carbon-concentrating mechanism of cyanobacteria.

Glycolate metabolism was further confirmed by the assessment of its metabolites. Amino acids (glycine and serine) and organic acids (glyceric, glycolic and glyoxylic acids) showed a time-dependent increase after $\mathrm{NaCl}$ treatment. Eisenhut et al. (2006) observed that a small change in the $\mathrm{CO}_{2}$ level, favouring photorespiratory conditions, resulted in a significant change in the glycine to serine ratio. Further, increased levels of glycine and serine induced by high salinity have been reported in Anabaena oryzae, $A$. doliolum and the chlorophyte Cladophora vagabunda (Alia \& Gahiza, 2007; Rani, 2007; Srivastava et al., 2008). Similar observations were also reported for rice when exposed to salt stress (Dubey \& Rani, 1989). The increase in serine content is confirmed by the overexpression of transcripts of genes of glycolate metabolism in general and of serine hydroxymethyltransferase (alr4806) in particular. Glycine and serine are not only the intermediates of glycolate metabolism but also play a significant role in maintaining the osmotic status of cells exposed to high salt concentrations (Kirst \& Bisson, 1979; Measures, 1975). 
The increase in organic acid content mirrors the upregulation of various genes involved in glycolate metabolism. Glycolate is a toxic compound and must be metabolized immediately. Thus, glycolate is converted to glyoxylate via the activity of glycolate oxidase, which would result in an increase of the glyoxylic acid content in the cells exposed to salt stress. Glyoxylate can be directly transaminated to glycine (Bergman, 1986); however, this may not be the major pathway for the metabolism of this compound due to increased serine and ammonia production (Srivastava et al., 2008). It is also known that nitrogen-fixing cyanobacteria (cultured in nitrogen-deficient medium) metabolize glycolate via the glycine and serine de novo pathway (Renström-Kellner \& Bergman, 1990). The increase in glyceric acid content results from enhanced respiration and glycolate metabolism in the salt-stressed cells, as reported previously (Srivastava et al., 2008). Although cyanobacteria have four different routes to metabolize glyoxylate, it is primarily metabolized through the photorespiratory process as in higher plants (Bergman, 1986; Bergman et al., 1985). Hyperaccumulation of glycolic and glyoxylic acid, as well as the observable increase in glycine and serine content in salt-stressed cells, supports the hypothesis of a photorespiratory pathway being present in Anabaena PCC 7120. However, the modest increases observed in the expression of particular transcripts and concentrations of metabolites involved in glycolate metabolism indicate that salinity does not completely disrupt the carbon-concentrating mechanism of this cyanobacterium.

\section{ACKNOWLEDGEMENTS}

A. K.S is grateful to the Australian Government for an Endeavour Research Fellowship-2009. Support from Mizoram University and the Department of Science and Technology, New Delhi is also gratefully acknowledged. This project and B. A. N are financially supported by the Australian Research Council. We are thankful to Professor Martin Hagemann, University of Rostock, Germany, for his valuable suggestions.

\section{REFERENCES}

Alia, E. A. \& Gahiza, I. A. (2007). Accumulation of amino acids in Anabaena oryzae in response to sodium chloride salinity. J Appl Sci Res 3, 263-266.

Badger, M. R. \& Price, G. D. (2003). $\mathrm{CO}_{2}$ concentrating mechanisms in cyanobacteria: molecular components, their diversity and evolution. J Exp Bot 54, 609-622.

Bauwe, H., Hagemann, M. \& Fernie, A. R. (2010). Photorespiration: players, partners and origin. Trends Plant Sci 15, 330-336.

Bergman, B. (1986). Glyoxylate induced changes in the carbon and nitrogen metabolism of the cyanobacterium Anabaena cylindrica. Plant Physiol 80, 698-701.

Bergman, B., Codd, G. A. \& Hällbom, L. (1984). Glycolate excretion by $\mathrm{N}_{2}$-fixing cyanobacteria treated with photorespiratory inhibitors. Z Pflanzenphysiol 113, 451-460.

Bergman, B., Renström, E., Hallborn, L. \& Codd, G. A. (1985). Effects of aminooxyacetate and aminoacetonitrile on glycolate and ammonia release by the cyanobacterium Anabaena cylindica. Plant Physiol 77, 536-539.

Betsche, T., Schaller, D. \& Melkonian, M. (1992). Identification and characterization of glycolate oxidase and related enzymes from the endocyanotic algae Cyanophora paradoxa and from pea leaves. Plant Physiol 98, 887-893.

Bhargava, P., Mishra, Y., Srivastava, A. K., Narayan, O. P. \& Rai, L. C. (2008). Excess copper induces anoxygenic photosynthesis in Anabaena doliolum: a homology based proteomic assessment of its survival strategy. Photosynth Res 96, 61-74.

Buick, R. (1992). The antiquity of oxygenic photosynthesis: evidence from stromatolites in sulphate-deficient Archaean lakes. Science 255, 74-77.

Chaves, M. M., Flexas, J. \& Pinheiro, C. (2009). Photosynthesis under drought and salt stress: regulation mechanisms from whole plant to cell. Ann Bot (Lond) 103, 551-560.

Colman, B. \& Norman, E. G. (1997). Serine synthesis in cyanobacteria by a nonphotorespiratory pathway. Physiol Plant 100, 133-136.

Dubey, R. S. \& Rani, M. (1989). Salinity induced accumulation of free amino acids in germinating rice seeds differing in salt tolerance. J Agron Crop Sci 163, 236-247.

Eckardt, N. A. (2005). Photorespiration revisited. Plant Cell 17, 2139 2141.

Eisenhut, M., Kahlon, S., Hasse, D., Ewald, R., Lieman-Hurwitz, J., Ogawa, T., Ruth, W., Bauwe, H., Kaplan, A. \& Hagemann, M. (2006). The plant-like $\mathrm{C}_{2}$ glycolate cycle and the bacterial-like glycerate pathway cooperate in phosphoglycolate metabolism in cyanobacteria. Plant Physiol 142, 333-342

Eisenhut, M., Ruth, W., Haimovich, M., Bauwe, H., Kaplan, A. \& Hagemann, M. (2008). The photorespiratory glycolate metabolism is essential for cyanobacteria and might have been conveyed endosymbiontically to plants. Proc Natl Acad Sci U S A 105, 17199-17204.

Ferjani, A., Mustardy, L., Sulpice, R., Marin, K., Suzuki, I., Hagemann, M. \& Murata, N. (2003). Glucosylglycerol, a compatible solute, sustains cell division under salt stress. Plant Physiol 131, 1628-1637.

Fulda, S., Huckauf, J., Schoor, A. \& Hagemann, M. (1999). Analysis of stress responses in the cyanobacterial strains Synechococcus sp. PCC 7942, Synechocystis sp. PCC 6803, and Synechococcus sp. PCC 7418: osmolyte accumulation and stress protein synthesis. J Plant Physiol 154, 240-249.

Fulda, S., Mikkat, S., Huang, F., Huckauf, J., Marin, K., Norling, B. \& Hagemann, M. (2006). Proteome analysis of salt stress response in the cyanobacterium Synechocystis sp. strain PCC 6803. Proteomics 6, 2733-2745.

Ginn, H. P., Pearson, L. A. \& Neilan, B. A. (2010). NtcA from Microcystis aeruginosa PCC 7806 is autoregulatory and binds to the microcystin promoter. Appl Environ Microbiol 76, 4362-4368.

Görg, A., Obermaier, C., Boguth, G. \& Weiss, W. (1999). Recent developments in two-dimensional gel electrophoresis with immobilized $\mathrm{pH}$ gradients: wide $\mathrm{pH}$ gradients up to $\mathrm{pH} 12$, longer separation distances and simplified procedures. Electrophoresis 20, 712-717.

Huang, F., Fulda, S., Hagemann, M. \& Norling, B. (2006). Proteomic screening of salt-stress-induced changes in plasma membranes of Synechocystis sp. strain PCC 6803. Proteomics 6, 910-920.

Kanesaki, Y., Suzuki, I., Allakhverdiev, S. I., Mikami, K. \& Murata, N. (2002). Salt stress and hyperosmotic stress regulate the expression of different sets of genes in Synechocystis sp. PCC 6803. Biochem Biophys Res Commun 290, 339-348.

Kirst, G. O. \& Bisson, M. A. (1979). Regulation in turgor pressure in marine algae: ions and low molecular weight organic compounds. Aust J Plant Physiol 6, 539-556. 
López, J. L. (2007). Two-dimensional electrophoresis in proteome expression analysis. J Chromatogr B Analyt Technol Biomed Life Sci 849, 190-202

Lu, C. \& Zhang, J. (2000). Role of light in the response of PSII photochemistry to salt stress in the cyanobacterium Spirulina platensis. J Exp Bot 51, 911-917

Marin, K., Kanesaki, Y., Los, D. A., Murata, N., Suzuki, I. \& Hagemann, M. (2004). Gene expression profiling reflects physiological processes in salt acclimation of Synechocystis sp. strain PCC 6803. Plant Physiol 136, 3290-3300

Measures, J. C. (1975). Role of amino acids in osmoregulation of non-halophilic bacteria. Nature 257, 398-400.

Moisander, P. H., McClinton, E., III \& Paerl, H. W. (2002). Salinity effects on growth, photosynthetic parameters, and nitrogenase activity in estuarine planktonic cyanobacteria. Microb Ecol 43, 432-442.

Neilan, B. A., Jacobs, D., Del Dot, T., Blackall, L. L., Hawkins, P. R., Cox, P. T. \& Goodman, A. E. (1997). rRNA sequences and evolutionary relationships among toxic and nontoxic cyanobacteria of the genus Microcystis. Int J Syst Bacteriol 47, 693-697.

Norman, E. G. \& Colman, B. (1988). Evidence for an incomplete glycolate pathway in cyanobacteria. J Plant Physiol 132, 766-768.

Norman, E. G. \& Colman, B. (1992). Formation and metabolism of glycolate in cyanobacterium Coccochloris peniocystis. Arch Microbiol 157, 375-380.

Pfaffl, M. W. (2001). A new mathematical model for relative quantification in real-time RT-PCR. Nucleic Acids Res 29, e45.

Rai, L. C. \& Raizada, M. (1985). Effect of nickel and silver ion on survival, growth, carbon fixation and nitrogenase activity in Nostoc muscorum: regulation of toxicity by EDTA and calcium. J Gen Appl Microbiol 31, 329-337.

Rani, G. (2007). Changes in protein profile and amino acids in Cladophora vagabunda (Chlorophyceae) in response to salinity stress. J Appl Phycol 19, 803-807.

Renström, E. \& Bergman, B. (1989). Glycolate metabolism in cyanobacteria. I Glycolate excretion and phosphoglycolate phosphatase activity. Physiol Plant 75, 137-143.

Renström-Kellner, E. \& Bergman, B. (1989). Glycolate metabolism in cyanobacteria. III. Nitrogen controls excretion and metabolism of glycolate in Anabaena cylindrica. Physiol Plant 77, 46-51.

Renström-Kellner, E. \& Bergman, B. (1990). Glycolate metabolism in cyanobacteria. IV. Uptake, growth and metabolic pathways. Physiol Plant 78, 285-292.
Schmidt-Goff, C. M. \& Federspiel, N. A. (1993). In vivo and in vitro footprinting of a light-regulated promoter in the cyanobacterium Fremyella diplosiphon. J Bacteriol 175, 1806-1813.

Seki, M., Ishida, J., Narusaka, M., Fujita, M., Nanjo, T., Umezawa, T., Kamiya, A., Nakajima, M., Enju, A. \& other authors (2002). Monitoring the expression pattern of around 7,000 Arabidopsis genes under ABA treatments using a full-length cDNA microarray. Funct Integr Genomics 2, 282-291.

Singh, R. N. (1961). Role of Blue-Green Algae in the Nitrogen Economy of Indian Agriculture. New Delhi: ICAR.

Sivakumar, P., Sharmila, P. \& Pardha Saradhi, P. (2000). Proline alleviates salt-stress-induced enhancement in ribulose-1,5-bisphosphate oxygenase activity. Biochem Biophys Res Commun 279, 512515.

Srivastava, A. K., Bhargava, P. \& Rai, L. C. (2005). Salinity and copper-induced oxidative damage and changes in the antioxidative defense system of Anabaena doliolum. World J Microbiol Biotechnol 21, 1291-1298.

Srivastava, A. K., Ara, A., Bhargava, P., Mishra, Y., Rai, S. P. \& Rai, L. C. (2007). A rapid and cost-effective method of genomic DNA isolation from cyanobacterial culture, mat and soil suitable for genomic fingerprinting and community analysis. J Appl Phycol 19, 373-382.

Srivastava, A. K., Bhargava, P., Thapar, R. \& Rai, L. C. (2008). Salinity-induced physiological and proteomic changes in Anabaena doliolum. Environ Exp Bot 64, 49-57.

Srivastava, A. K., Bhargava, P., Kumar, A., Rai, L. C. \& Neilan, B. A. (2009). Molecular characterization and effect of salinity on cyanobacterial diversity in the rice fields of Eastern Uttar Pradesh, India. Saline Syst 5, 4

Sudhir, P. R., Pogoryelov, D., Kovàcs, L., Garab, G. \& Murthy, S. D. S. (2005). The effect of salt stress on photosynthetic electron transport and thylakoid membrane proteins in the cyanobacterium Spirulina platensis. J Biochem Mol Biol 38, 481-485.

Thompson, A. S., Rhodes, J. C. \& Pettman, I. (1988). Culture Collection of Algae and Protozoa, Catalogue of Strains. Swindon, UK: National Environment Research Council.

Winicov, I. \& Seemann, J. R. (1990). Expression of genes for photosynthesis and the relationship to salt tolerance of alfalfa (Medicago sativa) cells. Plant Cell Physiol 31, 1155-1161.

Edited by: A. Wilde 